Primljen / Received: 13.3.2013. Ispravljen / Corrected: 20.11.2013. Prihvaćen / Accepted: 14.12.2013. Dostupno online / Available online: 10.1.2014.

\section{Determination of prestressing levels for cable trusses as a function of their stability}

Authors:

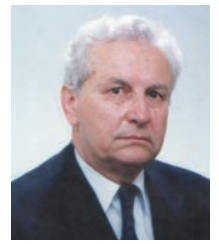

Prof. Mirko Aćić, PhD. CE

University of Belgrade

Faculty of Civil Engineering

(retired university professor)

acic.vlada@gmail.com

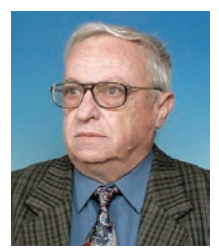

Prof. Ljubomir M. Vlajić, PhD. CE

University of Novi Sad

Faculty of Civil Engineering in Subotica

(retired university professor)

wlayc@gf.su.ac.rs

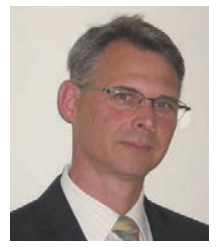

Assist.Prof. Dragan Kostić, PhD. CE University of Nis

Faculty of Civil Engineering and Architecture dragan.kostic@gaf.ni.ac.rs

\section{Mirko Aćić, Ljubomir M. Vlajić, Dragan Kostić}

\section{Determination of prestressing levels for cable trusses as a function of their stability}

The stability of prestressed cable trusses subjected to static and dynamic loads is analysed in the paper. The stiffness of the elastic cable truss system was varied by changing the prestressing force. Modelling results for different levels of tension show that, in terms of satisfying dynamic resistance conditions, a much greater tensile force is required for cable grids with diagonal members, compared to those with vertical rods. The conclusions derived constitute recommendations for the use of calculation methods, as well as for the determination of prestressing forces under which stability criteria are fulfilled.

Key words:

cable trusses, stability, stiffness, vibrations caused by wind, eigen and forced oscillations

Stručni rad

Mirko Aćić, Ljubomir M. Vlajič, Dragan Kostić

\section{Utvrdivanje razine prednaprezanja kabelskih rešetki u funkciji njihove stabilnosti}

U radu se analizira stabilnost prethodno napregnutih kabelskih rešetki na djelovanje statičkih i dinamičkih opterećenja. Krutost elastičnog sustava kabelskih rešetki varirana je promjenom sila prednaprezanja. Rezultati analiziranih modela za različite razine zategnutosti pokazali su da je u pogledu zadovoljenja uvjeta dinamičke otpornosti potrebna mnogo veća sila zatezanja za kabelske rešetke s dijagonalnim štapovima u odnosu na one s vertikalnim štapovima. Izvedeni zaključci su preporuka za primjenu metoda za proračun kao i utvrdivanje sila prednaprezanja pod kojima su ispunjeni uvjeti stabilnosti.

Ključne riječi:

kabelske rešetke, stabilnost, krutost, vibracije izazvane vjetrom, svojstvene i prinudne oscilacije

Fachbericht

Mirko Acíć, Ljubomir M. Vlajić, Dragan Kostić

\section{Bestimmung von Vorspannkräften in Seiltragwerken im Hinblick auf die Stabilität}

In dieser Arbeit wird die Stabilität vorgespannter Seiltragwerke unter statischen und dynamischen Kräften untersucht. Die Steifigkeit des elastischen Tragwerks wird durch die Annahme verschiedener Vorspannkräfte abgeändert. Die Resultate der für verschiedene Vorspannstufen analysierten Modele zeigen, dass für Seiltragwerke mit diagonalen Elementen bedeutend höhere Spannkräfte erforderlich sich, um die Bedingungen der dynamischen Beständigkeit zu erfüllen, als für Träger mit vertikalen Seilelementen. Abschließend werden Empfehlungen zur Anwendung von Berechnungsmethoden und zur Reihenfolge der Berechnungsschritte dargestellt, sowie die zur Erfüllung der Stabilitätskriterien erforderlichen Vorspannkräfte erläutert. 


\section{Introduction}

Cable trusses are double-layered catenary systems made of steel ropes. They form a system in a vertical plane together with the bearing and the stabilizing catenary, which are connected with either diagonal bars (type D, figure 2.A) or vertical bars (type V, Figure 2.B). By tensioning the lower stabilizing catenary the stressing forces are introduced in the entire system. In this way, the stiffness of these girders is achieved, i.e. their swinging in relation to asymmetrical and dynamic loads is prevented or limited.

Because of geometrical characteristics of catenaries and the rope structure, the bearing elements are elastic, making this system unstable if there are no tensile forces in the bars. This is particularly true for the lower stabilizing catenary which must have a tensile force even in the case when the girder is exposed to maximum gravity load caused by its own load, as well as by snow and wind $(g+s+w)$

Known methods for the stabilisation of these systems involve application of load to girders either by a weight, by prestressing or by combining with elements resistant to compression and bending. Structures in which the stabilisation by prestressing is applied will be analysed in this paper. The prestressing is a stabilization method that replaces the weight that would otherwise oppose asymmetrical external loads.

The prestressing force introduced into a girder is calculated through analytical relations as a consequence of an assumed "contact force" between the bearing cable and the prestressing cable. The inventor of these systems introduced the "contact force" as an additional fictive load (v) which will satisfy the necessary condition related to the tensioning of the stabilised catenary [1]. Professor Balgac also gave his analytical formulae for calculating "contact forces" $[17,18]$ in form of simple expressions which connect the additional load with geometrical characteristics of girders (span, depth, cross section) and the elastic modulus of the material.

The use of cable trusses has been improved during the past several decades by making appropriate changes to their basic form. Principal developments have been made in two directions: main girders in suspended systems, and primary semi-truss roof girders with a circular cable (Figure 1).

From the very first use of cable trusses, the dynamic influence of wind has been checked for all large-size suspended roof structures. In the 1960s, David Jawerth calculated for these structures the time periods of own vibrations according to original expressions for elastic systems [1]. Meteorological data about the speed, frequency, and direction of wind acting on the structure, and the duration of gusts, were analysed. On the basis of wind tunnel results, von Karman made nomograms in order to establish a relationship between forces in the girder support, rope diameter, Strowhale number, length of bar between nodes, and the speed of wind at which the resonance due to harmonic excitation may occur. By comparing the calculated own frequencies with the data from the von Karman nomogram, Jawerth determined whether the resonance would occur and, if so, at what wind speeds.

In the early 1980s, following a long period of disinterest after 1960s, Massimo Majowiecki [2] introduced a new use of cable nets (Figure 2.B), and his German colleagues accepted such structural solutions, and even contributed to the new concept (Figure 2A, Schlaich, Bergerman and Partner).

The use of computers in the process of calculation has contributed to the development of numerical procedures. Basic dynamic characteristics of cable nets were calculated using the subspace method, i.e. the Jacobi iterative algorithm. Majowietcki and Schlaih treated wind as a gust of sinusoid distribution of intensity which appears periodically, i.e. as a time-dependent load, in order to determine maximum movements and maximum forces in cable structure bars over a certain time interval. [2-6].

Bearing all this in mind, the authors of the paper analysed, in addition to force and displacement, the frequency spectrum of cable truss responses [7]. Two models were exposed to identical static and dynamic load. Diagrams of real-time changes of frequencies show that the occurrence of resonance is possible, and provide an answer to the question of stability,
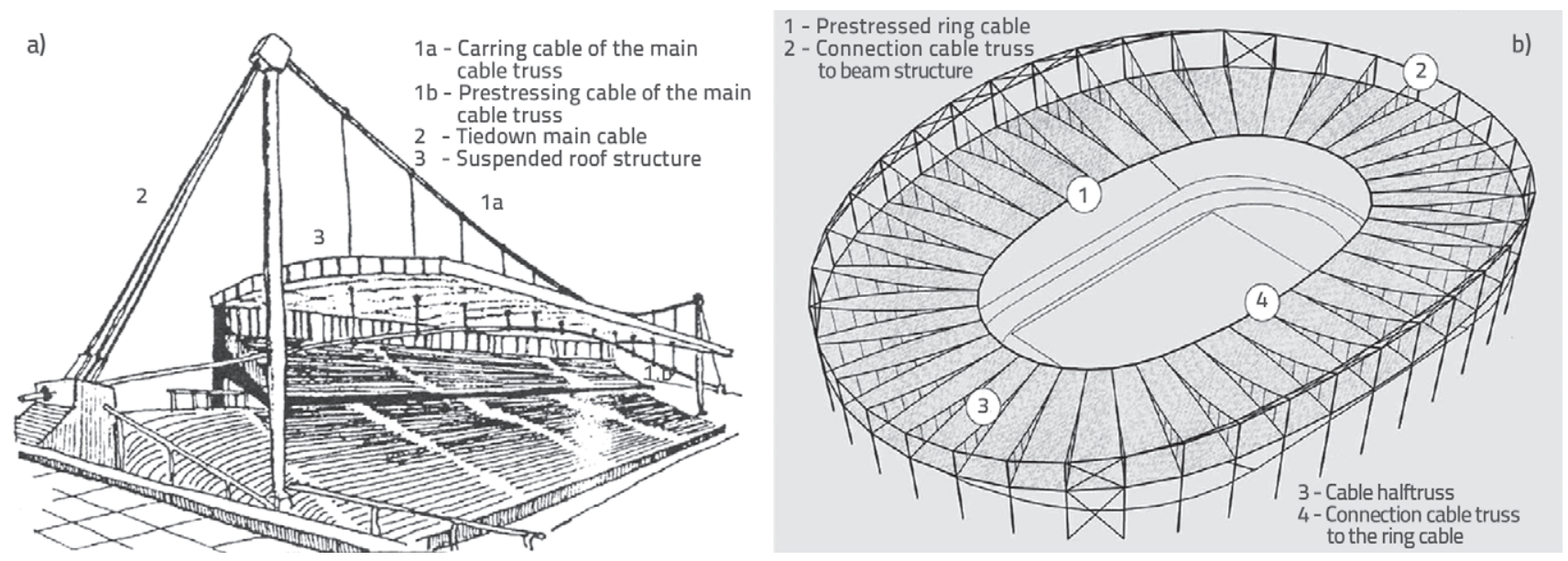

Figure 1. a) Main girder in suspended systems; b) Primary semi-truss girders 
i.e. the minimum prestressing level that guarantees fulfilment of previously-set stability criteria.

The aim of the paper is to estimate stability of cable nets as related to the fulfilment of known parameters (intensity of forces and displacement) caused by static and dynamic load, and a special emphasis is placed on the analysis of the frequency spectrum of concordance of the own and imposed oscillations. The result of the research provides an answer to the tensioning level of cable nets, as needed to meet known additional stability criteria for two basic models of these systems.

\section{Prestressing and stability criteria}

Prestressing is actually a substitution for load, i.e. it is its equivalent. The load was originally used as a real load for the stabilisation of catenary girders. The load caused by dynamic forces (wind or seismic action) induces inertia forces which exert a negative influence on the elastic girder of the catenary. The same effect is achieved by prestressing, albeit without inertia forces, which makes these lightweight roof structures susceptible to wind load, but not to seismic action.

The authors of the paper have recognized the need to establish a correlation between the minimum prestressing force and the additional fictive equivalent for which the girder would meet stability criteria.

\subsection{Stability criteria current practice}

Basic stability criteria have been defined by structural engineers and researchers in their papers. They are also summarized in provisions of the AISI Manual for Structural Applications of Steel Cables for Buildings. 2010 [8] and the Eurocode 3 [9]:

Criterion 1: Standardized wire cables, protected against corrosion, relaxed.

Criterion 2: The effective strength of a cable must be bigger than the biggest forces value in cables multiplied by an appropriate constant (1.6 up to 2.7 depending on the loading phase - ultimate limit state).

Criterion 3: Maximum allowed structural movements must not exceed the prescribed values (serviceability limit state).

Criterion 4: None of the cable elements must unstressed i.e., all of them must be tensioned.

Criterion 5: Conditions for achieving resonance and fake resonance must be avoided, in case the hanging roofs are exposed to dynamic load (wind, explosion or earthquake).

\subsection{Calculation analysis}

Because of their multiple static indetermination the calculations of such complex structures are highly complex. Two typical approaches are used for determining the stress and deformation: numerical [11-16] (Transient Stiffness Method, Force Density Method and Dynamic Relaxation Method) and analytical $[1,17,18]$.

Movements of nodes and forces in bars are obtained, for given geometrical parameters and load values, through calculation of these geometrical nonlinear structures. In order to meet stability criteria from Section 2.1, it is necessary to define minimum stressing forces caused by load influencing the roof girder and the additional load which causes the "contact force". This "contact force" is the direct consequence of the additional fictive loading " $v$ ". The contact force is the inner force between the bearing cable and the stabilizing cable, and it acts through filling rods (diagonal or vertical).

Through decomposition of cable trusses into layer cables in the phase of the greatest gravity load, the upper bearing cable assumes all external loads and an additional fictive load $(\mathrm{g}+\mathrm{s}$ $+w+v)$, while the lower stabilizing cable is affected only by an additional fictive load (v), when the contact force between the cables is the smallest, just like the force in the stabilizing cable. Through the unloading of cable trusses the contact force between the cables increases $(v+k)$, and the girder itself elastically moves upwards for the change in depth $\Delta \mathrm{f}$ when the depth of the stabilizing cable increases $\left(f_{p}+\Delta f\right)$, and that of the bearing cable decreases $\left(f_{n}-\Delta f\right)$. The unloading causes an increase of forces in the stabilizing cable and a decrease in the bearing cable. A reverse process occurs if load is exerted on the girder [7].

In fact, the need to determine displacements and forces in cable truss ropes, in accordance with stability criteria from section 2.1, has prompted the authors to conduct an analysis based on analytical and numerical methods presented in this paper, during which it would be possible to control the contact force in accordance with recommended additional fictive load values for cables.

Numerical procedures, i.e. the Force Density Method and the Dynamic Relaxation Method, quickly lead to the convergence of the iterative procedure with a minimum of input data. The intensity of prestressing force is one of significant input data. This data is inserted based on recommendations that are not precisely defined, and the result of calculation concerning fulfilment of stability criteria is unknown. The use of these methods most often results in insufficient structure tensioning forces, and the calculation procedure must be repeated by increasing the prestressing level, until all stability conditions from Section 2.1. are met.

That is why the authors have chosen a combination of the analytical and numerical approach, i.e. the Transient Stiffness Method [7]. The analytical method uses conditions of balance and the change of catenary length at load, thus forming systems of nonlinear differential equations. Through approximations and eliminations of small higher-order values, the equations are made linear and are reduced to an easily solved problem, with the calculation error from $6 \%$ to $10 \%$. The shortcomings of both methods are turned to their advantage through appropriate combination of their results. 
The imprecision due to approximation, and the length of analytical procedure, are not necessarily shortcomings, as the procedure can be conducted using computer programmes, and so the time needed can be reduced significantly while, in this relation, the imprecision can be tolerated as the data obtained by analytic procedure will be treated numerically, using the Transient Stiffness Method. The shortcoming of this numerical method is the multitude of necessary input data about configuration of the system and prestressing forces in bars. This, however, is obtained in the scope of the analytical method and so, in this case, this is not a shortcoming but rather a quality in the combined use of the two methods.

A modified analytical procedure developed by professor Balgac $[7,17,18]$ was used in order to obtain the data about the system configuration and the forces in the so called referential position. This procedure was adapted to the cable truss calculation, due to some limiting elements that had to be substituted by general ones, so that the calculation can be applied to a larger number of problems. The calculation adapted in this way was used to write programme modules for computer, according to which the cable-truss referential position parameters can rapidly be found with great accuracy. The quality of analytical procedure proposed by Professor Balgac lies in the condition according to which the stabilizing cable must keep in itself the stressing force even under the highest gravity load, and the vertical component of this force, the so called "contact force", will be exerted on the bearing cable through some fictive load "v". The presence of "contact force" guarantees stability of the roof. The static calculation must be followed by dynamic analysis so that fulfilment of criterion 5 from Subsection 2.1 can be checked. Cable structures behave as geometrically nonlinear structures in both static and dynamic way. However, the linearization is made in the dynamic analysis in order to simplify the problem and reduce the calculation time.

The modal analysis is used to determine Eigen frequencies and Eigen shapes of the oscillation of structures. It is also used as the basis for other detailed dynamic analyses such as: transient analysis, harmonic analysis, and spectral analysis. For the problem with prestressing, geometrical nonlinearity, possible great deformations, and an increase in stiffness with an increase in tensioning force, the most favourable method is the subspace method, according to the instructions for the use of the program package "ANSYS MultiPhysics", Houston 2003.

The transient dynamic analysis, also known as the "time history" analysis, is the method by which the dynamic response of a structure subjected to a time-dependent load is obtained $(F(t))$. This type of dynamic analysis was used in order to determine time-dependent movements and forces in the structure, and to see whether the structure reacts to any combination of static, transient, or harmonic loads. The change of load over time, and inertia or damping effects, exert a significant influence on the analysis results.
Basic movement equations are solved by the Newmark"s time integration in defined time "spots". The so called full method was used for solving the problem of transient vibrations caused by wind action.

The transient stiffness method, or the method of final displacements, as it was called on the day it was created, was used for static and dynamic calculations. The cable truss model was made of the so-called link finite elements. They are spatial elements with alternating tension and compression, without stiffness to bending. Every element has two nodes, each of them with three degrees of freedom ( $u$, $\mathrm{v}, \mathrm{w}$ ). They are appropriate for nonlinear analysis, analysis of big deformations, presence of prestressing forces, increase of model stiffness caused by an increase of their inner forces, and for dynamic analysis with possible damping. External forces act in nodes, just like concentrated masses in dynamic analysis.

\section{Estimation of prestressing level as a function of cable truss stability}

The level of prestressing of cable trusses is estimated through analysis of results obtained by analytical and numerical static analyses, and by modal, harmonic and transient analysis. Structural analysis is conducted for defined loads (dead load, snow and wind), which are increased by an additional fictive load "v", in order to obtain the "contact force".

The span of cable trusses was chosen according to the needs of a covered universal arena, bearing in mind the number of spectators $(<5000)$ corresponding to the needs of a small town in Serbia. The chosen span was $L=60,00 \mathrm{~m}$ (Figure 2).
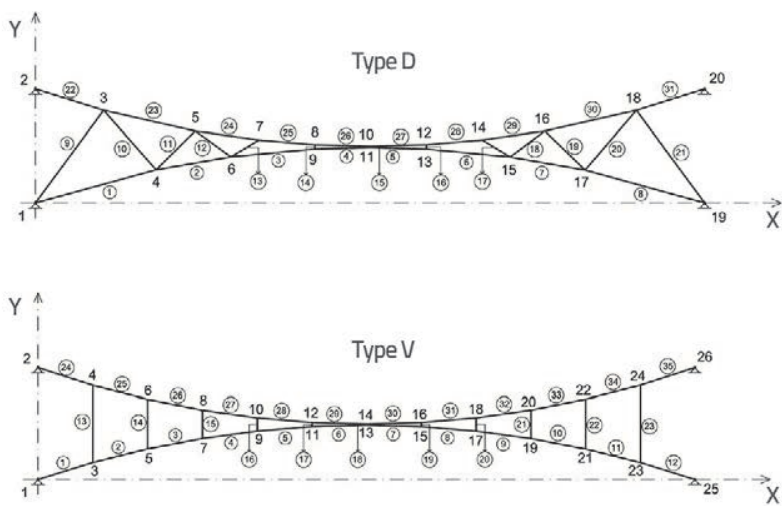

Figure 2. Models of cable trusses: a) Type $D$ with diagonal filling rods; b) Type $V$ with vertical filling rods

Geometrical and physic characteristics of the chosen cable truss models, i.e. structural scheme of girder configuration, span, distance between cable trusses, and their support and loading system, are given in Table 1. According to the manufacturer"s catalogue, the elasticity modulus of selected cables amounts to $E=165 \mathrm{kN} / \mathrm{mm}^{2}$. 
Table 1 Structural characteristics of the chosen cable models

\begin{tabular}{|c|c|c|c|c|c|c|c|c|c|}
\hline \multicolumn{2}{|c|}{$\begin{array}{l}\text { Type of structure } \\
\text { Geometrical characteristics }\end{array}$} & \multicolumn{4}{|c|}{ Type "D" } & \multicolumn{4}{|c|}{ Type "V" } \\
\hline \multicolumn{2}{|c|}{ Girders span } & \multicolumn{4}{|c|}{$60 \mathrm{~m}$} & \multicolumn{4}{|c|}{$60 \mathrm{~m}$} \\
\hline \multicolumn{2}{|c|}{ Mutual girders span } & \multicolumn{4}{|c|}{$5 \mathrm{~m}$} & \multicolumn{4}{|c|}{$5 \mathrm{~m}$} \\
\hline \multicolumn{2}{|c|}{ Cable depth: bearing / prestressed } & \multicolumn{4}{|c|}{$4,9 \mathrm{~m} / 4,9 \mathrm{~m}$} & \multicolumn{4}{|c|}{$4,9 \mathrm{~m} / 4,9 \mathrm{~m}$} \\
\hline \multicolumn{2}{|c|}{ Geometrical form of cable } & \multicolumn{4}{|c|}{ square parable } & \multicolumn{4}{|c|}{ square parable } \\
\hline \multicolumn{2}{|c|}{ Support type } & \multicolumn{4}{|c|}{ with unmovable supports } & \multicolumn{4}{|c|}{ with unmovable supports } \\
\hline \multicolumn{2}{|c|}{ Number of structural nodes } & \multicolumn{4}{|c|}{20} & \multicolumn{4}{|c|}{26} \\
\hline \multicolumn{2}{|c|}{ free/supporting nodes } & \multicolumn{4}{|c|}{$16 / 4$} & \multicolumn{4}{|c|}{$22 / 4$} \\
\hline \multicolumn{2}{|c|}{ Number of bars } & \multicolumn{4}{|c|}{31} & \multicolumn{4}{|c|}{35} \\
\hline \multicolumn{2}{|c|}{ bearing/diagonal/ stabilizing } & \multicolumn{4}{|c|}{$8 / 13 / 10$} & \multicolumn{4}{|c|}{$12 / 11 / 12$} \\
\hline \multicolumn{2}{|c|}{ Loads $\left[\mathrm{kN} / \mathrm{m}^{2}\right]$} & $\begin{array}{l}\text { Ultra } \\
\text { light }\end{array}$ & Very light & Light & $\begin{array}{l}\text { Medium } \\
\text { heavy }\end{array}$ & $\begin{array}{l}\text { Ultra } \\
\text { light }\end{array}$ & Very light & Light & $\begin{array}{l}\text { Medium } \\
\text { heavy }\end{array}$ \\
\hline \multicolumn{2}{|c|}{$\mathrm{g}=$ dead weight } & 0,15 & 0,30 & 0,50 & 0,75 & 0,15 & 0,30 & 0,50 & 0,75 \\
\hline \multicolumn{2}{|c|}{$\mathrm{s}=\mathrm{snow}$} & 1,00 & 1,00 & 1,00 & 1,00 & 1,00 & 1,00 & 1,00 & 1,00 \\
\hline \multicolumn{2}{|c|}{$\mathrm{w}_{\mathrm{s}}=$ wind: constant suction } & $-0,48$ & $-0,48$ & $-0,48$ & $-0,48$ & $-0,48$ & $-0,48$ & $-0,48$ & $-0,48$ \\
\hline \multicolumn{2}{|c|}{$\mathrm{w}_{\mathrm{s}}=$ wind: constant pressure } & 0,17 & 0,17 & 0,17 & 0,17 & 0,17 & 0,17 & 0,17 & 0,17 \\
\hline $\mathrm{w}_{\mathrm{d}}=$ wind: $\mathrm{c}$ & c suction & $-0,80$ & $-0,80$ & $-0,80$ & $-0,80$ & $-0,80$ & $-0,80$ & $-0,80$ & $-0,80$ \\
\hline $\begin{array}{l}v=\text { "contact force" (p } \\
\text { additional fic }\end{array}$ & $\begin{array}{l}\text { sing equivalent of } \\
\text { ad) }\left[\mathrm{kN} / \mathrm{m}^{2}\right]\end{array}$ & $\begin{array}{l}0,05 \\
0,10 \\
0,15 \\
0,20 \\
0,70\end{array}$ & $\begin{array}{l}0,05 \\
0,10 \\
0,15 \\
0,20 \\
0,50\end{array}$ & $\begin{array}{l}0,05 \\
0,10 \\
0,15 \\
0,20 \\
0,35\end{array}$ & $\begin{array}{l}0,05 \\
0,10 \\
0,15 \\
0,20\end{array}$ & $\begin{array}{l}0,05 \\
0,10 \\
0,15 \\
0,20\end{array}$ & $\begin{array}{l}0,05 \\
0,10 \\
0,15 \\
0,20\end{array}$ & $\begin{array}{l}0,05 \\
0,10 \\
0,15 \\
0,20\end{array}$ & $\begin{array}{l}0,05 \\
0,10 \\
0,15 \\
0,20\end{array}$ \\
\hline $\begin{array}{l}\text { Cross section area } \\
{\left[\mathrm{mm}^{2}\right]}\end{array}$ & $\begin{array}{l}\text { bearing } \\
\text { filling } \\
\text { stabilizing }\end{array}$ & $\begin{array}{l}953 \\
400 \\
555\end{array}$ & $\begin{array}{l}1105 \\
400 \\
555\end{array}$ & $\begin{array}{l}1219 \\
400 \\
555\end{array}$ & $\begin{array}{c}1399 \\
400 \\
555\end{array}$ & $\begin{array}{l}953 \\
400 \\
555\end{array}$ & $\begin{array}{l}1105 \\
400 \\
555\end{array}$ & $\begin{array}{l}1219 \\
400 \\
555\end{array}$ & $\begin{array}{c}1399 \\
400 \\
555\end{array}$ \\
\hline $\begin{array}{l}\text { Chosen ropes } \\
\Phi[\mathrm{mm}]\end{array}$ & $\begin{array}{l}\text { bearing } \\
\text { filling } \\
\text { stabilizing }\end{array}$ & $\begin{array}{l}\text { Ф } 38 \\
\text { Ф25 } \\
\text { Ф29 }\end{array}$ & $\begin{array}{l}\Phi 40 \\
\Phi 25 \\
\Phi 29\end{array}$ & $\begin{array}{l}\Phi 42 \\
\Phi 25 \\
\Phi 29\end{array}$ & $\begin{array}{l}\Phi 45 \\
\Phi 25 \\
\Phi 29\end{array}$ & $\begin{array}{l}\Phi 38 \\
\Phi 25 \\
\Phi 29\end{array}$ & $\begin{array}{l}\Phi 40 \\
\Phi 25 \\
\Phi 29\end{array}$ & $\begin{array}{l}\Phi 42 \\
\Phi 25 \\
\Phi 29\end{array}$ & $\begin{array}{l}\Phi 45 \\
\Phi 25 \\
\Phi 29\end{array}$ \\
\hline
\end{tabular}

\subsection{Dynamic wind load on high-rise structures}

Realistically expected loads are defined according to prevailing technical regulations, whereas the wind is analysed as a horizontal laminar motion, i.e. as a random and continuous process, which is defined according to principles used in mathematical statistics, turbulent flow mechanics, and structural theory, $[4,6,10,16]$.

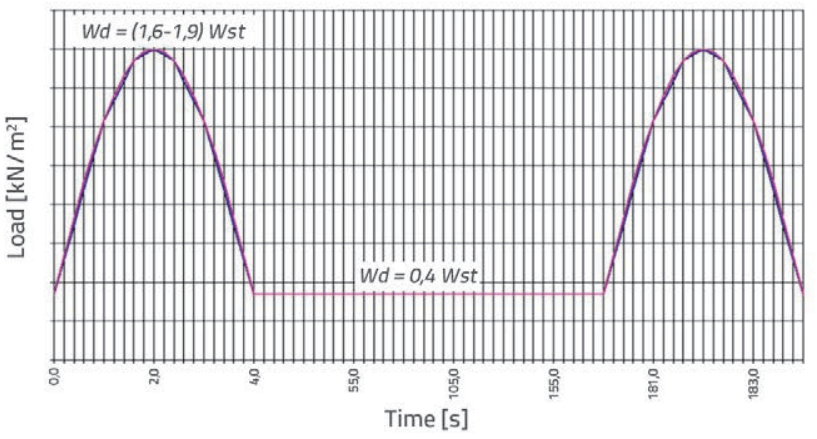

Figure 3. Dynamic effect of Košava wind for the 10 minute average wind velocity, according to Schlaich [6]
On the basis of meteorological and statistical data, the wind was treated as a load whose intensity varies at each moment in time, actually as a stochastic excitation which is divided into a harmonious force with the frequency of $0-0.4 \mathrm{~Hz}$, and a dynamic impulse force repeating at specific time intervals after a period of "lull" (Figure 3 and Figure 4). The dynamic force of wind is present in nodes of the upper cable truss layer, according to distribution shown in Figure 4.b. During the "lull" period the girder is influenced by the harmonious wind excitation force ranging from $0 \mathrm{~Hz}$ to $0.4 \mathrm{~Hz}$ (Figure 4). a)

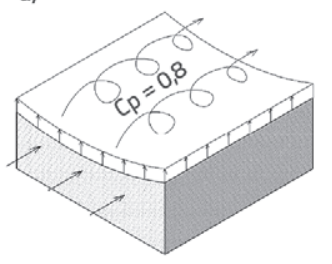

b)

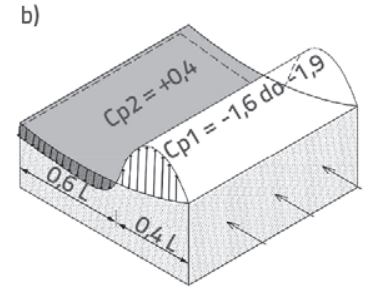

Figure 4. Wind action on structure, depending on wind direction: a) Harmonious force of wind suction; b) Wind gust force 
Table 2. Calculated values of forces and movements in relation to stability criteria ( $\mathrm{N}$ - not fulfilled, $\mathrm{Y}$ - fulfilled)

\begin{tabular}{|c|c|c|c|c|c|c|c|}
\hline & lity criterions & Crite & ion 2 & Criterion 3 & & Criterion 4 & \\
\hline $\begin{array}{l}\text { Cable trusses } \\
\text { Load }(\mathrm{g}, \mathrm{v})[\mathrm{k}\end{array}$ & & $\begin{array}{c}\text { Effective forces } \\
\text { in the bearing } \\
\text { cable }\end{array}$ & $\begin{array}{c}\text { Effective forces } \\
\text { in the stabilizing } \\
\text { cable }\end{array}$ & $\begin{array}{l}\text { Displacements } \\
{[\mathrm{m}]}\end{array}$ & & $\begin{array}{l}\text { unstressed } \\
\text { pressure ro }\end{array}$ & \\
\hline & & $S_{\text {allowed }}=$ & $\mathrm{S}_{\mathrm{calc}}[\mathrm{kN}]$ & nodal 10 & bearing ${ }^{*}$ & stabilizing ${ }^{*}$ & diagonal \\
\hline & & $S_{\text {tear }}=1421$ & $\mathrm{~S}_{\text {tear }}=827$ & $w_{\text {allow }}=0,24$ & & & \\
\hline & $v=0,05$ & 1249 & 487 & 0,291 & $Y(76 \%)$ & $Y(15 \%)$ & $\mathrm{N}$-some \\
\hline$g=0,15$ & $v=0,10$ & 1309 & 543 & 0,300 & $Y(80 \%)$ & $Y(40 \%)$ & $\mathrm{N}$-some \\
\hline & $v=0,15$ & 1344 & 579 & 0,297 & $Y(81 \%)$ & $Y(39 \%)$ & $\mathrm{N}$-some \\
\hline & $v=0,20$ & 1389 & 603 & 0,295 & $Y(82 \%)$ & $Y(36 \%)$ & Some \\
\hline & & $S_{\text {tear }}=1649$ & $S_{\text {tear }}=827$ & $w_{\text {allow }}=0,24$ & & & \\
\hline & $v=0,05$ & 1402 & 448 & 0,243 & Y (91\%) & $Y(14 \%)$ & $\mathrm{N}$-some \\
\hline$g=0,30$ & $v=0,10$ & 1453 & 489 & 0,256 & $Y(95 \%)$ & $Y(33 \%)$ & $\mathrm{N}$-some \\
\hline & $v=0,15$ & 1497 & 531 & 0,253 & $Y(93 \%)$ & $Y(37 \%)$ & $\mathrm{N}$-some \\
\hline & $v=0,20$ & 1541 & 577 & 0,254 & $Y(106 \%)$ & $Y(42 \%)$ & $\mathrm{N}$-some \\
\hline & & $S_{\text {tear }}=1818$ & $S_{\text {tear }}=827$ & $w_{\text {allow }}=0,24$ & & & \\
\hline & $v=0,05$ & 1604 & 493 & 0,209 & $Y(108 \%)$ & $Y(8,5 \%)$ & $\mathrm{N}$-some \\
\hline$g=0,50$ & $v=0,10$ & 1648 & 514 & 0,220 & $Y(108 \%)$ & $Y(34 \%)$ & $\mathrm{N}$-some \\
\hline & $v=0,15$ & 1699 & 561 & 0,217 & $Y(106 \%)$ & $Y(38 \%)$ & $\mathrm{N}$-some \\
\hline & $v=0,20$ & 1742 & 605 & 0,218 & $Y(106 \%)$ & $Y(43 \%)$ & $\mathrm{N}$-some \\
\hline & & $S_{\text {tear }}=2087$ & $S_{\text {tear }}=827$ & $\mathrm{w}_{\text {allow }}=0,24$ & & & \\
\hline & $v=0,05$ & 1737 & 495 & 0,191 & $Y(130 \%)$ & $Y(10 \%)$ & $\mathrm{N}$-some \\
\hline$g=0,75$ & $v=0,10$ & 1900 & 542 & 0,203 & $Y(126 \%)$ & $Y(34 \%)$ & $\mathrm{N}$-some \\
\hline & $v=0,15$ & 1951 & 588 & 0,203 & $Y(125 \%)$ & $Y(40 \%)$ & $\mathrm{N}$-some \\
\hline & $v=0,20$ & 1944 & 635 & 0,201 & $Y(123 \%)$ & $Y(44 \%)$ & $\mathrm{N}$-some \\
\hline & & $\mathrm{S}_{\text {allow }}$ & $\mathrm{S}_{\text {tear }}$ & nodal 14 & bearing* & prestressed $^{*}$ & vertical $^{*}$ \\
\hline & & $S_{\text {tear }}=1421$ & $\mathrm{~S}_{\text {tear }}=827$ & $\mathrm{w}_{\text {allow }}=0,24$ & & & \\
\hline & $v=0,05$ & 1211 & 497 & 0,319 & $Y(71 \%)$ & $Y(14 \%)$ & $\mathrm{N}$-some \\
\hline$g=0,15$ & $v=0,10$ & 1259 & 540 & 0,299 & $Y(74 \%)$ & $Y(14 \%)$ & $\mathrm{N}$-some \\
\hline & $v=0,15$ & 1308 & 587 & 0,332 & $Y(76 \%)$ & $Y(30 \%)$ & $\mathrm{N}$-some \\
\hline & $v=0,20$ & 1357 & 647 & 0,325 & $Y(78 \%)$ & $Y(35 \%)$ & $X(35 \%)$ \\
\hline & & $S_{\text {tear }}=1649$ & $\mathrm{~S}_{\text {tear }}=827$ & $w_{\text {allow }}=0,24$ & & & \\
\hline & $v=0,05$ & 1362 & 499 & 0,283 & $Y(91 \%)$ & $Y(12 \%)$ & $\mathrm{N}$-some \\
\hline$g=0,30$ & $v=0,10$ & 1410 & 535 & 0,267 & $Y(91 \%)$ & $Y(11 \%)$ & $\mathrm{N}$-some \\
\hline & $v=0,15$ & 1459 & 572 & 0,300 & $Y(92 \%)$ & $Y(29 \%)$ & $\mathrm{N}$-some \\
\hline & $v=0,20$ & 1508 & 611 & 0,293 & $Y(92 \%)$ & $Y(35 \%)$ & $Y(34 \%)$ \\
\hline & & $S_{\text {tear }}=1818$ & $S_{\text {tear }}=827$ & $w_{\text {allow }}=0,24$ & & & \\
\hline & $v=0,05$ & 1561 & 472 & 0,254 & $Y(96 \%)$ & $Y(8 \%)$ & $\mathrm{N}$-some \\
\hline$g=0,50$ & $v=0,10$ & 1609 & 520 & 0,278 & $Y(96 \%)$ & $Y(22 \%)$ & $\mathrm{N}$-some \\
\hline & $v=0,15$ & 1658 & 567 & 0,273 & $Y(96 \%)$ & $Y(29 \%)$ & $Y(28 \%)$ \\
\hline & $v=0,20$ & 1705 & 614 & 0,269 & $Y(96 \%)$ & $Y(34 \%)$ & $Y(33 \%)$ \\
\hline & & $\mathrm{S}_{\text {tear }}=2087$ & $S_{\text {tear }}=827$ & $\mathrm{w}_{\text {allow }}=0,24$ & & & \\
\hline & $v=0,05$ & 1811 & 499 & 0,231 & $Y(96 \%)$ & $Y(8 \%)$ & $\mathrm{N}$-some \\
\hline$g=0,75$ & $v=0,10$ & 1859 & 547 & 0,248 & $Y(96 \%)$ & $Y(22 \%)$ & $\mathrm{N}$-some \\
\hline & $v=0,15$ & 1906 & 594 & 0,244 & $Y(96 \%)$ & $Y(28 \%)$ & $Y(27 \%)$ \\
\hline & $v=0,20$ & 1954 & 641 & 0,241 & Y (96\%) & $Y(34 \%)$ & $Y(32 \%)$ \\
\hline
\end{tabular}




\subsection{Static analysis of adopted models}

A cable truss model, $60 \mathrm{~m}$ in span, is considered for various categories of dead weight of roof cover (ultra lightweight $=0.15 \mathrm{kN} / \mathrm{m}^{2}$, very lightweight $=0.30 \mathrm{kN} / \mathrm{m}^{2}$, lightweight $=0.50 \mathrm{kN} / \mathrm{m}^{2}$ and medium weight $=0.75 \mathrm{kN} / \mathrm{m}^{2}$ roof covers). At that, each cable truss "D" and "V" is exposed to realistic load combinations ( 6 combinations of static and 4 combinations of dynamic load), while its stiffness level is varied. This stiffness level is defined by the "contact force" and by an additional fictive load ranging from $v=0.05$ to $0.70 \mathrm{kN} / \mathrm{m}^{2}$.

The stability of adopted models under the influence of static load is analysed in accordance with criteria given in Section 2.1. (criteria 2 to 4). The maximum allowed force $\left(F_{\text {allow }}=\right.$ $\left.\mathrm{K}_{\mathrm{i}} \cdot \mathrm{S}_{\text {calcul }}\right)$ is the maximum calculated force multiplied by an appropriate constant depending on the loading phase. The condition is that $F_{\text {allow }}<F_{\text {tear }}$. The failure force is taken from the manufacturer's catalogue.

Movements of model nodes (w) are calculated in relation to the structure's condition under its own load, i.e. in relation to the so-called design condition, and should be lower than $\mathrm{L} / 250=0.24 \mathrm{~m}$.

Results obtained by static analysis point to initial prestressing levels under which fulfilment of static and dynamic stability conditions for individual load constellations can be expected. The static analysis was conducted according to the algorithm of the Transient Stiffness Method using the program module CABL-N [7].

Conclusions about fulfilment of stability criteria are reached by analysis of each model separately and also by comparison. The criteria set, fulfilled either completely or partly, provide solutions for solving the problem of cable truss stability for static load.

At that, some of the analysed models:

- can under some conditions be considered as "statically stable" structures, because they are fully compliant with the criterion 2, and partly with criteria 3 and 4 (U).

- can be accepted as stable structures for static load because they are fully compliant with criteria 2, 3 and 4 (StSt - statically stable).

Table 3 clearly presents statically stable models according to roof load categories and prestressing (additional fictive load) levels. No model can be considered an unstable structure with respect to static loads. In order to be confirmed as comprehensively stable, those models that are marked as conditionally statically stable (C) and statically stable (StSt) must fulfil the dynamic stability conditions, through analysis of modal forms, frequencies, superposition of modal and harmonic vibrations, and response to time-dependent load.
Table 3 Fulfillment of static stability criteria

\begin{tabular}{|c|c|c|c|c|c|}
\hline \multirow{2}{*}{$\begin{array}{l}\text { Model } \\
\text { type }\end{array}$} & \multirow{2}{*}{$\begin{array}{l}\text { Additional } \\
\text { fictive load }\end{array}$} & \multicolumn{4}{|c|}{$\begin{array}{l}\text { Roof load categories } \\
\qquad\left[\mathrm{kN} / \mathrm{m}^{2}\right]\end{array}$} \\
\hline & & $g=0,15$ & $g=0,30$ & $g=0,50$ & $g=0,75$ \\
\hline \multirow{4}{*}{ Type "D" } & $v=0,05$ & $U$ & $U$ & U & $U$ \\
\hline & $v=0,10$ & $U$ & $U$ & StSt & StSt \\
\hline & $v=0,15$ & $U$ & $U$ & StSt & StSt \\
\hline & $v=0,20$ & $U$ & $U$ & StSt & StSt \\
\hline \multirow{4}{*}{ Type "V" } & $v=0,05$ & $U$ & $U$ & $U$ & $U$ \\
\hline & $v=0,10$ & $U$ & $U$ & $U$ & StSt \\
\hline & $v=0,15$ & $U$ & $U$ & StSt & StSt \\
\hline & $v=0,20$ & StSt & StSt & StSt & StSt \\
\hline \multicolumn{6}{|c|}{ U - conditionally fulfilled; StSt - statically stable } \\
\hline
\end{tabular}

\subsection{Modal analysis of adopted models}

The modal analysis defines basic dynamic characteristics of a structure (own frequencies and own shapes) which are not dependent on the loading or support movements, or damping, but are functionally related to initial parameters: configuration of the system (position of nodes in space and their connection with rods), material properties, and inner forces due to prestressing. Consequently, modal parameters differ for balance states $g+w$ and $g+s+w$. The method of inverse iterations (Subspace Method) was chosen for calculating modal parameters because it is highly accurate (full matrices $[\mathrm{K}]$ and $[\mathrm{M}]$ are used). From the programming standpoint, it enables superposition of tone forms in subsequent dynamic analysis (harmonious superposition of modal shapes and transient superposition of modal shapes).

Modal analysis was made using ANSYS on a spatial model consisting of "link" elements. The program module CABL-T [7], based on prof. Balgacs"s modified analytical procedure, was used in the preparatory phase to determine the system configuration and forces in rods in a reference position (prestressing phase). Out of 10 eigen forms obtained, only the first to fourth forms are tones in vertical plane $(x O y)$, while the others occur in horizontal plane $(\mathrm{xOz})$, or the eigen vectors are negligibly small (order of $1 \cdot E^{-7}$ ). It is obvious that the frequencies increase and periods of oscillations decrease with an increase in the prestressing level, i.e. with an increase in the model tensioning level.

Eigen frequency values are higher for model " $D$ " than for model "V", and for the load category " $g+w$ " as compared to " $g$ $+\mathrm{s}+\mathrm{w}$ ", as shown in Table 4 for the first two oscillation tones. The modal form participation factor is the largest for the first and second eigen forms of vibration in the xOy plane. Through analysis of similarity of modal forms, the common first and second characteristic modal forms are summarised depending on variable factors: additional fictive load $v$ (which is due to prestressing) and static load phases $\mathrm{g}+\mathrm{w}$ and $\mathrm{g}+\mathrm{s}+\mathrm{w}$, as presented in the Table 5 . 
Table 4. Modal parameters for the first two oscillation tones

\begin{tabular}{|c|c|c|c|c|c|c|c|c|c|}
\hline \multirow{3}{*}{\multicolumn{2}{|c|}{ Type of structure }} & \multicolumn{4}{|c|}{$\begin{array}{c}\text { Type "D" } \\
\text { Eigen frequencies }[\mathrm{Hz}]\end{array}$} & \multicolumn{4}{|c|}{$\begin{array}{c}\text { Type "V" } \\
\text { Eigen frequencies }[\mathrm{Hz}]\end{array}$} \\
\hline & & \multicolumn{2}{|c|}{$g+w$} & \multicolumn{2}{|c|}{$g+s+w$} & \multicolumn{2}{|c|}{$g+w$} & \multicolumn{2}{|c|}{$g+s+w$} \\
\hline & & I ton & II ton & I ton & II ton & I ton & II ton & I ton & II ton \\
\hline \multirow{7}{*}{$g=0,15$} & $v=0,05$ & 4,156 & 5,696 & 3,862 & 5,302 & 3,144 & 4,198 & & \\
\hline & $v=0,10$ & 4,357 & 5,634 & 3,972 & 5,452 & 3,237 & 4,353 & 3,402 & - \\
\hline & $v=0,15$ & 4,477 & 5,710 & 4,039 & 5,541 & 3,330 & 4,503 & 3,509 & 5,027 \\
\hline & $v=0,20$ & 4,627 & 5,799 & 4,124 & 5,652 & 3,433 & 4,658 & 3,734 & 5,295 \\
\hline & $v=0,50$ & 5,297 & 6,150 & & & & & & \\
\hline & $v=0,60$ & 4,491 & 5,745 & 4,668 & 6,303 & & & & \\
\hline & $v=0,70$ & 4,665 & 5,984 & 4,810 & 6,449 & & & & \\
\hline \multirow{7}{*}{$g=0,30$} & $v=0,05$ & 4,325 & 5,675 & 3,898 & 5,390 & 3,130 & 4,259 & - & - \\
\hline & $v=0,10$ & 4,486 & 5,778 & 3,989 & 5,513 & 3,234 & 4,422 & 3,472 & - \\
\hline & $v=0,15$ & 4,627 & 5,860 & 4,070 & 5,621 & 3,334 & 4,572 & 3,577 & 5,142 \\
\hline & $v=0,20$ & 4,761 & 5,934 & 4,148 & 5,723 & 3,443 & 4,728 & 3,689 & 5,282 \\
\hline & $v=0,30$ & 5,021 & 6,067 & & & & & & \\
\hline & $v=0,40$ & 5,261 & 6,185 & & & & & & \\
\hline & $v=0,50$ & 4,475 & 5,669 & 4,588 & 6,258 & & & & \\
\hline \multirow{5}{*}{$g=0,50$} & $v=0,05$ & 4,633 & 5,923 & 4,033 & 5,569 & 3,214 & 4,457 & - & - \\
\hline & $v=0,10$ & 4,761 & 5,991 & 4,109 & 5,669 & 3,315 & 4,603 & 3,595 & - \\
\hline & $v=0,15$ & 4,887 & 6,055 & 4,184 & 5,766 & 3,417 & 4,746 & 3,697 & 5,320 \\
\hline & $v=0,20$ & 5,009 & 6,114 & 4,257 & 5,859 & 3,519 & 4,884 & 3,798 & 5,442 \\
\hline & $v=0,30$ & 4,829 & 5,941 & & & & & & \\
\hline \multirow{4}{*}{$g=0,75$} & $v=0,05$ & 4,888 & 6,103 & 4,133 & 5,711 & 3,283 & 4,621 & - & - \\
\hline & $v=0,10$ & 4,658 & 5,678 & 4,203 & 5,800 & 3,384 & 4,757 & 3,700 & - \\
\hline & $v=0,15$ & 4,284 & 5,190 & 4,271 & 5,887 & 3,487 & 4,894 & 3,800 & 5,467 \\
\hline & $v=0,20$ & 4,363 & 5,312 & 4,340 & 5,972 & 3,586 & 5,022 & 3,895 & 5,577 \\
\hline
\end{tabular}

Table 5. Typical shapes of vertical eigen forms for model types "D" and "V" ( $Y$ correspondence of own shapes with shapes given in the table)

\begin{tabular}{|c|c|c|c|c|c|c|c|c|c|c|c|c|}
\hline \multirow{2}{*}{\multicolumn{2}{|c|}{\begin{tabular}{|c|} 
Load phase \\
Aadditional fictive load $\mathrm{v}\left[\mathrm{kN} / \mathrm{m}^{2}\right]$
\end{tabular}}} & \multicolumn{7}{|c|}{$\mathrm{g}+\mathrm{w}\left[\mathrm{kN} / \mathrm{m}^{2}\right]$} & \multicolumn{4}{|c|}{$\mathrm{g}+\mathrm{s}+\mathrm{w}\left[\mathrm{kN} / \mathrm{m}^{2}\right]$} \\
\hline & & 0.05 & 0.10 & 0.15 & 0.20 & $0.30^{*}$ & $0.40^{*}$ & $0.50^{*}$ & 0.05 & 0.10 & 0.15 & 0.20 \\
\hline \multirow{4}{*}{ I svojstveni oblik } & 0.15 & $\mathrm{~N}$ & $\mathrm{~N}$ & $\mathrm{~N}$ & $\mathrm{~N}$ & $\mathrm{~N}$ & $\mathrm{~N}$ & $\mathrm{~N}$ & & & & \\
\hline & 0.30 & $\mathrm{~N}$ & $\mathrm{~N}$ & $\mathrm{~N}$ & $\mathrm{~N}$ & $\mathrm{~N}$ & $\mathrm{~N}$ & & & & & \\
\hline & 0.50 & $\mathrm{~N}$ & $\mathrm{~N}$ & $\mathrm{~N}$ & $\mathrm{~N}$ & & & & & & & \\
\hline & 0.75 & $\mathrm{~N}$ & & & & & & & & & & \\
\hline \multicolumn{2}{|c|}{ Aadditional fictive load $v\left[\mathrm{kN} / \mathrm{m}^{2}\right]$} & 0.15 & 0.20 & $0.30^{*}$ & $0.40^{*}$ & $0.50^{*}$ & $0.60^{*}$ & $0.70^{*}$ & 0.05 & 0.10 & 0.15 & 0.20 \\
\hline \multirow{4}{*}{ I svojstveni oblik } & 0.15 & & & & & & Y & Y & Y & Y & Y & Y \\
\hline & 0.30 & & & & & Y & & & Y & $\mathrm{Y}$ & Y & Y \\
\hline & 0.50 & & & Y & & & & & $\mathrm{Y}$ & $\mathrm{Y}$ & $\mathrm{Y}$ & Y \\
\hline & 0.75 & Y & Y & & & & & & Y & Y & Y & Y \\
\hline \multicolumn{2}{|c|}{ Aadditional fictive load $v\left[\mathrm{kN} / \mathrm{m}^{2}\right]$} & 0.05 & 0.10 & 0.15 & 0.20 & & & & 0.05 & 0.10 & 0.15 & 0.20 \\
\hline \multirow{4}{*}{ II svojstveni oblik } & 0.15 & Y & Y & Y & Y & & & & & & $\mathrm{Y}$ & Y \\
\hline & 0.30 & Y & Y & Y & Y & & & & & & Y & Y \\
\hline & 0.50 & Y & Y & Y & Y & & & & & & Y & Y \\
\hline & 0.75 & Y & Y & Y & Y & & & & & & $Y$ & Y \\
\hline
\end{tabular}

${ }^{*}$ Additional fictive load was increased during the calculation until the correspondence between common eigen oscillation forms in phases "g+w" i "g+s+w" was reached. 
The common eigen modal forms occurring in characteristic critical static load phases $(g+w$ and $g+s+w$ ) point to potential additional fictive load under which one may expects fulfilment of dynamic stability condition 5 from chapter 2.1 (checked and coloured fields in Table 5).

\subsection{Harmonic analysis of adopted models}

The harmonic calculation was conducted using the software package ANSYS. Possible occurrence of great strain and nonlinear response of the model imposed the need to use the modal procedure (inverse iteration method) and harmonic analysis (mode superposition method). Results expected in this phase of dynamic analysis are model node displacement amplitudes as a function of the attack harmonic wind force frequency $w_{h}$ (cosine frequency function of $\mathrm{OHz}$ up to $0.4 \mathrm{~Hz}$, Figure 4.a).

By superposing ten obtained eigen forms and oscillations obtained by harmonic wind excitation $\left(w_{h}\right)$ in the defined frequency range from 0 to $0.4 \mathrm{~Hz}$, the amplitudes of the oscillatory motion of the upper layer model nodes are obtained. By increasing the prestressing level, that is by increasing the tension of the model, the oscillation amplitudes due to harmonic wind excitation are reduced.

Maximum oscillations for the model "D" will occur at the highest load for " $\mathrm{g}+\mathrm{s}+\mathrm{w}_{\mathrm{h}}$ ", while amplitudes are considerably lower for the model "V" for both critical load phases " $\mathrm{g}+\mathrm{w}_{\mathrm{h}}$ " and " $\mathrm{g}+\mathrm{s}+\mathrm{w}_{\mathrm{h}}$ ". The analysis of amplitude change graphs, for the frequency range from $0 \mathrm{~Hz}$ to $0.4 \mathrm{~Hz}$, clearly demonstrates that the amplitudes are constant and that no resonance will occur as a result of the adopted harmonic excitation. The resonance would occur in case the wind would generate the harmonic excitation of about $4 \mathrm{~Hz}$ which, is impossible in our weather conditions.

\subsection{Transient analysis of adopted models}

The transient analysis or the momentary excitation analysis defines the model"s response in real time, by applying loads to the model that can be a variable according to some known regularity, or according to a given time record. As the problem under study is geometrically nonlinear, taking the calculated values from the static analysis, and using the prestressing command, the transient analysis will be calculated as a nonlinear problem which is linearized, with the possibility of model deformation and development of forces in the members, which will change at any given moment.

In the analysis of wind phenomenon, the action of horizontal laminar air movement has been defined as harmonic in the frequency range between $0 \mathrm{~Hz}$ and $0.4 \mathrm{~Hz}$ (Figure 4.a), and as an impact-turbulent action that is repeated in the time interval of 180 seconds, with the duration of 4 seconds during which it obtains its dynamic maximum according to the sine distribution, as presented in Figures 3 and 4. The force of wind is distributed along nodes of the upper girder cable, according to Figure 4.b, and is present in the vertical plane only.
Considering the nature of the problem, it would be necessary to apply a procedure for the analysis of prestressed geometrically non-linear problems, in which large deformations and superposition of eigen and enforced oscillation forms can occur. This is why the program package ANSYS, enabling transient analysis with the so called full method, was applied (full Newton-Raphson with a variable stiffness matrix). The model consists of "Link" elements that accept only axial tension or compression forces. The constant oscillation damping of $5 \%$ was applied according to elastic characteristics of the structure, recommendations, and ANSYS manual instructions. Dynamic equilibrium equations in the transient analysis are solved using the direct Newmark integration method for the given time intervals. Initial displacement, velocity and acceleration values, as obtained by static analysis, constitute the necessary condition for completing the transient analysis. The mode superposition command enables superposition of displacements obtained by transient analysis and modal analysis and, at that, normalised typical vectors are transposed before superposition with the transient analysis results.

Characteristic critical loads of the model are $g+w_{\text {dinamic }}$ and $g+s+w_{\text {dinamic }}$ with the wind induced excitation force changing as a function of time $w(t)$. Calculation results are real displacements of selected model nodes, member forces, and model oscillation frequencies, over a given time period, i.e. during the momentary dynamic excitation, which corresponds to the time interval of 185 seconds, as shown in Figure 3.

It can be seen from the results that the highest displacements occur in the nodes affected by the strongest dynamic force (node "5" for model "D",and node "6" for model "V"), at the moment of its maximum intensity ( $t=3 \mathrm{sec}$ ). After the dynamic force has stopped acting, at the moment $\mathrm{t}=5 \mathrm{sec}$, the model, due to its elasticity, continues to oscillate by vibration, i.e. via amplitudes on both sides of the equilibrium position, which vary from $0.6 \mathrm{~mm}$ to $15 \mathrm{~mm}$. These vibration amplitudes approach very quickly the model equilibrium position, i.e. the model starts to oscillate by characteristic eigen frequencies of the first or the second tone.

Model "D" vibration: oscillations around the balance position in the vertical plane with the amplitude of $15 \mathrm{~mm}$ continue until the next dynamic impact of wind in rhythmical intervals of 25 to 30 seconds, where the period of recurrence of vibration is longer for the load phase $g+s+w_{d}$

Model "V" vibration: oscillations around the balance position in the vertical plane with the amplitude of $11 \mathrm{~mm}$ continue until the next dynamic impact of wind in rhythmical intervals of 18 to 21 seconds, where the period of recurrence of vibration is longer for the load phase $g+s+w_{d}$.

The criterion of fulfilment of maximum permissible force in analysed models is satisfied for all load phases and prestressing levels, except for the type " $D$ " model with the ultra lightweight roof cover of $\mathrm{g}=0.15 \mathrm{kN} / \mathrm{m}^{2}$ for $\mathrm{g}+\mathrm{s}+\mathrm{w}_{\mathrm{d}^{\prime}}$, where this criterion was exceeded by $10.3 \%$. This excess can be solved by adopting the first larger cross section of the support cable. 
a)

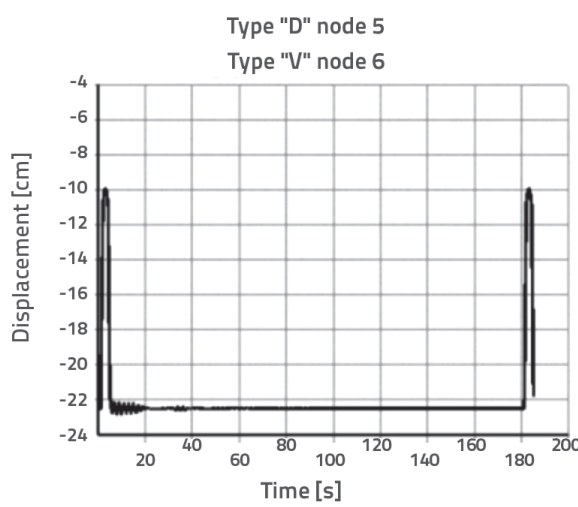

c)

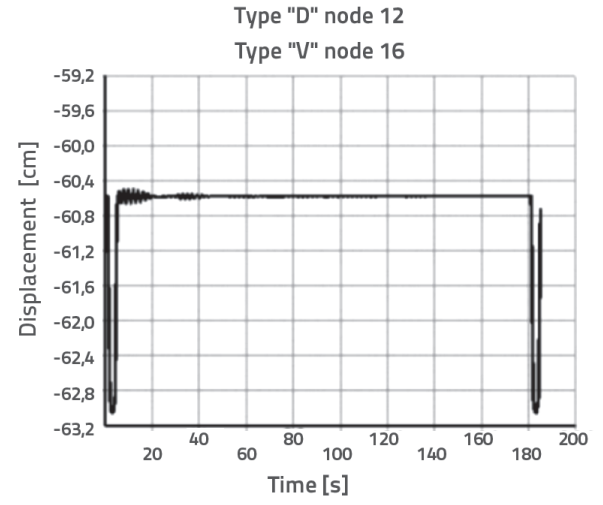

b)

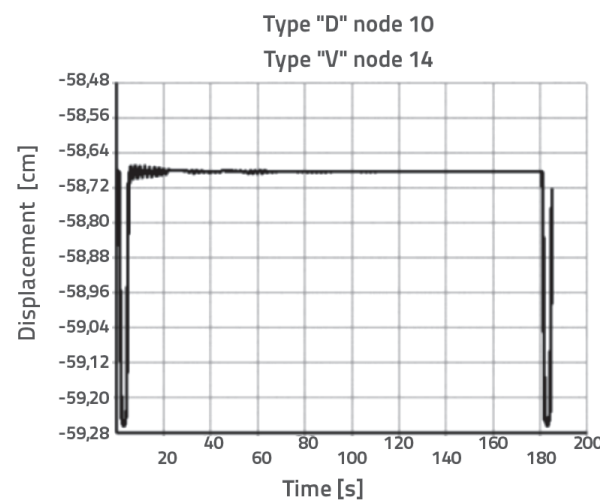

d)

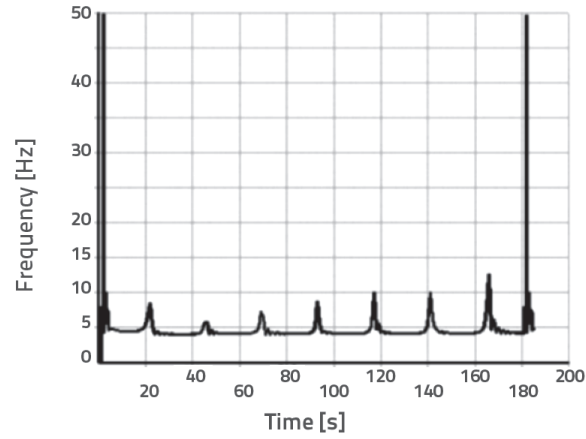

Figure 5. Combination l: displacement diagrams (a, b, c), and frequency spectrum (d)

a)

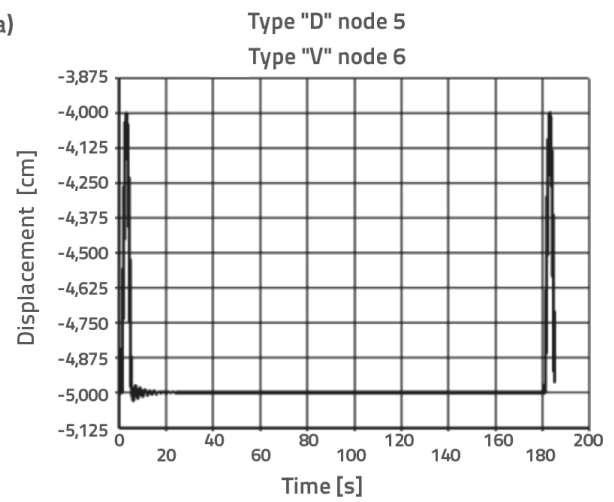

Type "D" node 12

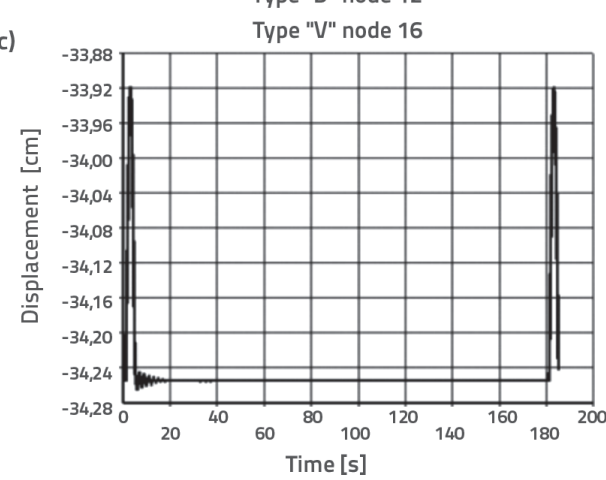

b)

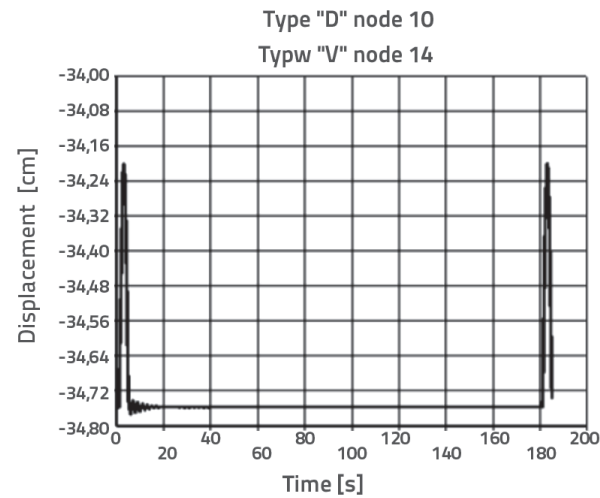

d)

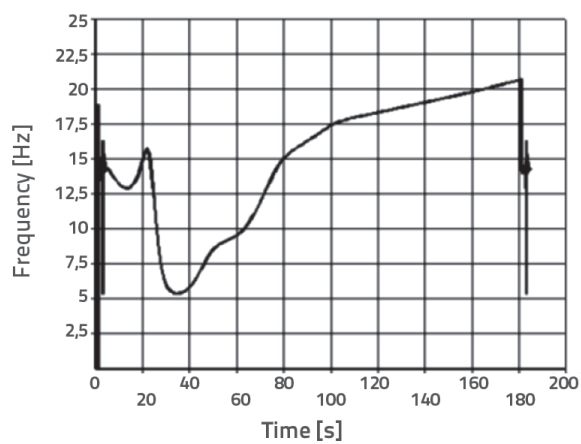

Figure 6. Combination II: displacement diagrams (a, b, c), and frequency spectrum (d) 

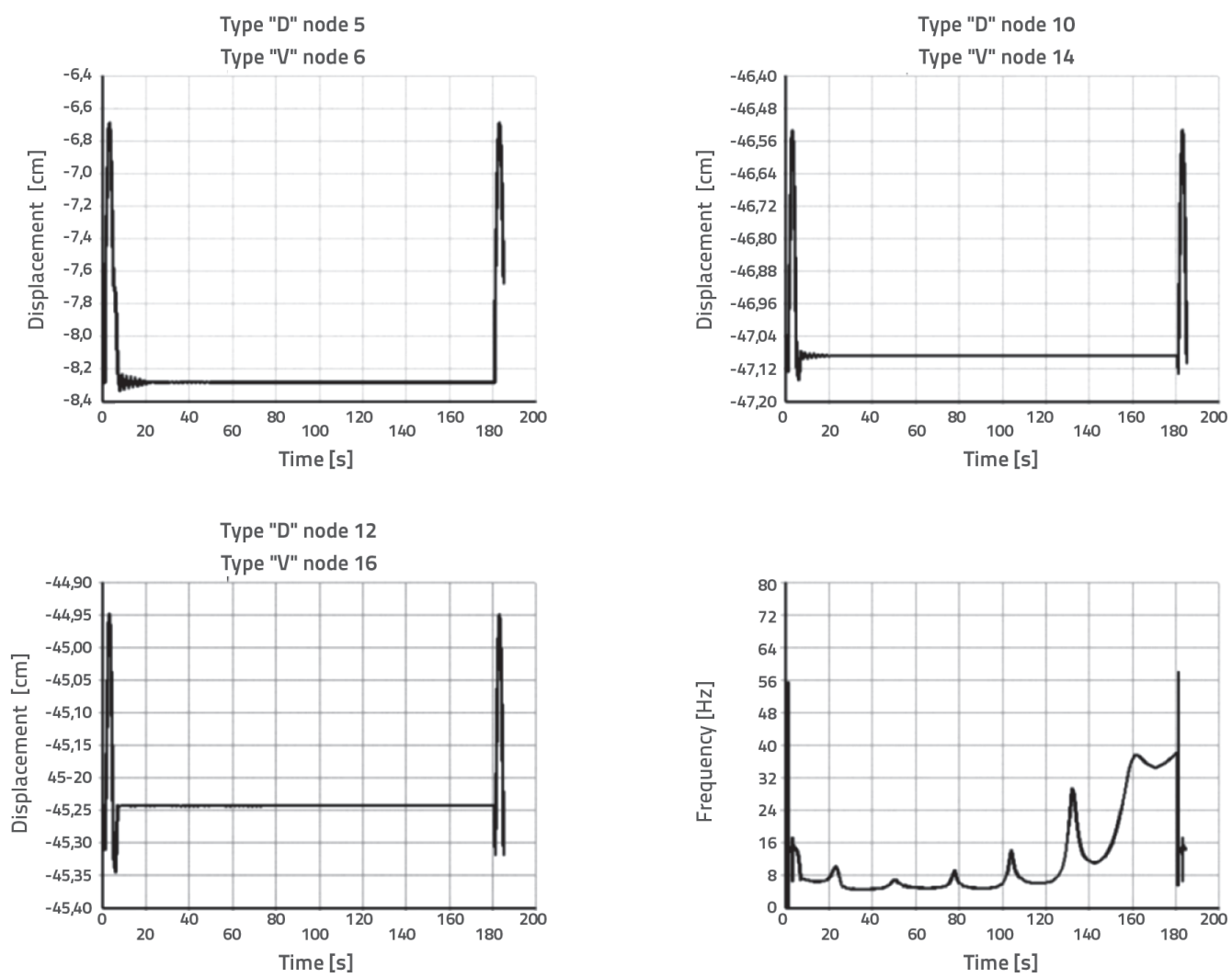

Figure 7. Combination III: displacement diagrams (a, b, c), and frequency spectrum (d)

Table 6. Typical forms of vertical displacement of model nodes and frequency spectrum, arranged by similarity of diagrams from figures 5 to 7

\begin{tabular}{|c|c|c|c|c|c|c|c|c|c|c|c|c|c|}
\hline \multicolumn{3}{|c|}{$\begin{array}{l}\text { Type of } \\
\text { structure and loads }\end{array}$} & \multicolumn{7}{|c|}{$\begin{array}{c}g+w \\
{\left[\mathrm{kN} / \mathrm{m}^{2}\right]}\end{array}$} & \multicolumn{4}{|c|}{$\begin{array}{l}\mathrm{g}+\mathrm{s}+\mathrm{w} \\
{\left[\mathrm{kN} / \mathrm{m}^{2}\right]}\end{array}$} \\
\hline \multirow{10}{*}{ 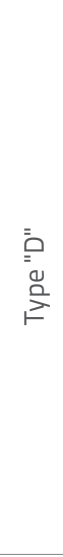 } & \multicolumn{2}{|c|}{$\begin{array}{c}\text { Additional fictive load } \\
\qquad \mathrm{v}\left[\mathrm{kN} / \mathrm{m}^{2}\right]\end{array}$} & 0.05 & 0.10 & 0.15 & 0.20 & 0.30 & 0.40 & 0.50 & 0.05 & 0.10 & 0.15 & 0.20 \\
\hline & \multirow{4}{*}{ Combination II } & 0.15 & Y2 & Y2 & $Y 2$ & $Y 2$ & Y2 & Y2 & Y2 & & & & \\
\hline & & 0.30 & $\mathrm{Y} 2$ & Y2 & Y2 & $Y 2$ & Y2 & Y2 & & & & & \\
\hline & & 0.50 & Y2 & Y2 & Y2 & Y2 & & & & & & & \\
\hline & & 0.75 & $\mathrm{Y} 2$ & Y2 & & & & & & & & & \\
\hline & \multicolumn{2}{|c|}{$\begin{array}{l}\text { Additional fictive load } \\
\qquad \mathrm{v}\left[\mathrm{kN} / \mathrm{m}^{2}\right]\end{array}$} & 0.15 & 0.20 & 0.30 & 0.35 & 0.50 & 0.60 & 0.70 & 0.05 & 0.10 & 0.15 & 0.20 \\
\hline & \multirow{4}{*}{$\begin{array}{l}\text { Combination I } \\
\text { Combination III }\end{array}$} & 0.15 & & & & & & Y3 & Y1 & Y1 & Y1 & Y1 & Y1 \\
\hline & & 0.30 & & & & & Y3 & & & $\mathrm{Y} 1$ & Y1 & Y1 & Y1 \\
\hline & & 0.50 & & & Y3 & Y1 & & & & $\mathrm{Y} 1$ & Y1 & Y1 & Y1 \\
\hline & & 0.75 & Y3 & Y1 & & & & & & $\mathrm{Y} 1$ & Y1 & Y1 & Y1 \\
\hline \multirow{5}{*}{ 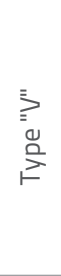 } & \multicolumn{2}{|c|}{$\begin{array}{l}\text { Additional fictive load } \\
\qquad v\left[\mathrm{kN} / \mathrm{m}^{2}\right]\end{array}$} & 0.05 & 0.10 & 0.15 & 0.20 & & & & 0.05 & 0.10 & 0.15 & 0.20 \\
\hline & \multirow{4}{*}{ Combination I } & 0.15 & Y1 & Y1 & Y1 & Y1 & & & & & Y1 & Y1 & Y1 \\
\hline & & 0.30 & Y1 & Y1 & Y1 & Y1 & & & & & Y1 & Y1 & $\mathrm{Y} 1$ \\
\hline & & 0.50 & Y1 & $\mathrm{Y} 1$ & Y1 & Y1 & & & & & Y1 & Y1 & Y1 \\
\hline & & 0.75 & Y1 & Y1 & $\mathrm{Y} 1$ & Y1 & & & & Y1 & Y1 & Y1 & Y1 \\
\hline
\end{tabular}


The transient analysis yielded frequency change diagrams, i.e. the frequency spectrum of models in the time interval of dynamic excitation (0 to 185 seconds). The frequency change diagram presented in Figure 5 shows a model oscillating in the first characteristic form with rhythmical vibrations. The frequency change diagram given in Figure 6 presents a model that "wanders about" in search for its characteristic oscillation form, and so, generally, this structure cannot be considered as dynamically resistant.

Common diagram combinations, shown in Figures 5, 6 and 7, are summarized through the analysis of similarity between diagrams, displacements of characteristic nodes, and frequency change diagrams. Combinations of these diagrams are repeated depending on the factors that are subject to change: additional fictive forces $v$ and load phases $g+w_{d} i g+$ $\mathrm{s}+\mathrm{w}_{\mathrm{d}}$, as presented in Table 6 .

Common similar combinations of the mentioned diagrams, occurring at characteristic critical load phases ( $g+w d$ i $g+5+w d)$, point to such pre-stressing levels at which one may expect fulfilment of dynamic stability conditions (fields $Y 1$ and $Y 3$ in Table 6), i.e. due to the transient excitation - occasional wind excitations - the model quickly calms down to the level of lower characteristic frequencies (preferably to the first characteristic frequency).

\section{Discussion of results}

Dynamic analysis results were obtained using the ANSYS programme, through modal analysis, harmonic analysis of superposition of modal and harmonic oscillations, and transient analysis of the model"s behaviour during the time-dependent loading. Abundant results were obtained through numerous analyses on "D" and "V" models for four roof weight categories, and static and dynamic service loads. Based on a comprehensive analysis of existing structures, recommendations given by some authors $[1,11,17,18]$, and according to appropriate results, the authors of this papers specified and additionally elaborated the stability criteria 3,4 and 5 from Section 2.1 of this paper. The following criteria were used in the analysis of dynamic resistance of cable trusses:

1. None of the cable elements should be unstressed, i.e. cable elements in each loading phase must be stressed. Minimum force intensity should be no less than $20 \%$ of the force present in the rope during prestressing.

2. The own modal shapes should be as simple as possible.

3. Maximum allowed structure node amplitudes, resulting from the superposition of modal and harmonic oscillations, should be limited to $\delta_{\max }=\mathrm{L} / 200$, where $\delta_{\max }$ is the maximum displacement of the structure in relation to the design position (phase of load by dead-weight, $g$ );

4. Conditions that enable resonance through harmonic excitation, which leads to large deformations, must be avoided, i.e. modal frequencies must be influenced by the level of prestressing so that they do not correspond to the frequency of imposed harmonic excitations;

5. Due to transient excitation - occasional wind gusts - the model should be quickly calmed down to the level of lower eigenfrequencies (to the level one if possible). Transient analysis results should be used to define frequency changes diagrams. Possible shapes of these diagrams point to the model which oscillates in the first own shape with rhythmical amplitudes (Figure 8.a), and to the model which "wanders about" looking for its own shape of oscillation (Figure 8.b) and so, from the dynamic standpoint, it cannot be considered as a sufficiently resistant structure.

The above mentioned dynamic-stability criteria were used to form Table 7, which shows numerical and descriptive indicators of the level of fulfilment of individual criteria.

Results obtained point to minimum prestressing forces that are due to the existence of the "contact force", i.e. of an additional fictive load " $v$ " that should influence the cable-truss stabilizing rope in the phase of the largest gravity load, in order to obtain the overall stability of the

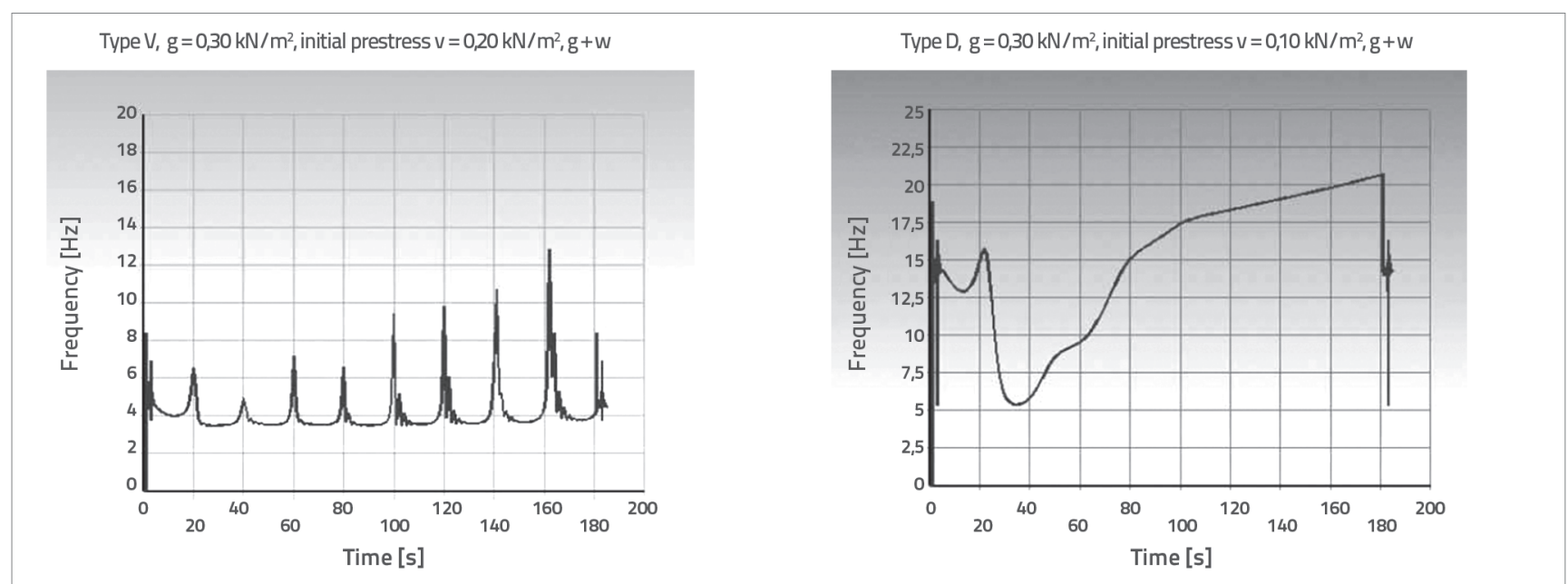

Figure 8. Frequency change diagram: a) dynamically resistant model; b) dynamically non-resistant model 
Table 7. Fulfilment of dynamic stability criteria (Y-fulfilled, $\mathrm{N}$-not fulfilled)

\begin{tabular}{|c|c|c|c|c|c|c|c|c|}
\hline \multirow{2}{*}{\multicolumn{2}{|c|}{$\begin{array}{c}\text { Model type }(D, V) \\
\text { category of dead weight, } \\
\text { prestressing levels }\end{array}$}} & \multicolumn{5}{|c|}{ Tranzijent analiza } & \multirow[b]{2}{*}{$\begin{array}{l}\text { Amplitudes } \\
\text { caused by } \\
\text { superposition } \\
\text { of modal and } \\
\text { harmonic. } \\
\text { oscillations }\end{array}$} & \multirow[b]{2}{*}{$\begin{array}{l}\text { Simple modal } \\
\text { shapes }\end{array}$} \\
\hline & & $\begin{array}{c}\text { Effective } \\
\text { forces in } \\
\text { carrying cable } \\
{[\mathrm{kN}]}\end{array}$ & $\begin{array}{c}\text { Effective forces } \\
\text { in stabilizing } \\
\text { cable } \\
{[\mathrm{kN}]}\end{array}$ & $\begin{array}{c}\text { Oscillation } \\
\text { amplitude } \\
\text { [m] }\end{array}$ & $\begin{array}{l}\text { Unstressed } \\
\text { rods }\end{array}$ & $\begin{array}{l}\text { Frequecy } \\
\text { response } \\
\text { spectrum for } \\
\text { dynamically } \\
\text { resistant } \\
\text { model }\end{array}$ & & \\
\hline \multicolumn{2}{|c|}{ Type "D" } & \multicolumn{2}{|c|}{$\begin{array}{c}\mathrm{S}_{\text {allowed }}=\mathrm{K}_{\mathrm{i}} \mathrm{S}_{\text {calc }} \\
{[\mathrm{kNN}]}\end{array}$} & $\begin{array}{c}\text { node } 5 \\
{[\mathrm{~m}]}\end{array}$ & $\begin{array}{c}* \text { Prestressing } \\
{[\%]}\end{array}$ & $g+w$ i g+s+w & node 5 & tones I and II \\
\hline & $\mathrm{S}_{\text {tearing }}$ & 1421 & 827 & $w<0,3$ & & & & \\
\hline \multirow{3}{*}{$g=0,15$} & $v=0,15$ & 1230 & 421 & 0,126 & X (30\%) & $\mathrm{N}$ & $Y$ & $\mathrm{~N}$ \\
\hline & $v=0,20$ & 1264 & 473 & 0,134 & $X(34 \%)$ & $\mathrm{N}$ & Y & $\mathrm{N}$ \\
\hline & $v=0,70$ & 1568 & 944 & 0,142 & X (61 \%) & Y & Y & Y \\
\hline \multirow{4}{*}{$g=0,30$} & $\mathrm{~S}_{\text {tearing }}$ & 1649 & 827 & $w<0,3$ & & & & \\
\hline & $v=0,15$ & 1391 & 429 & 0,133 & $X(33 \%)$ & $\mathrm{N}$ & Y & $\mathrm{N}$ \\
\hline & $v=0,20$ & 1426 & 481 & 0,139 & $X(38 \%)$ & $\mathrm{N}$ & Y & $\mathrm{N}$ \\
\hline & $v=0,50$ & 1636 & 804 & 0,139 & $X(58 \%)$ & $Y$ & Y & $Y$ \\
\hline \multirow{4}{*}{$g=0,50$} & $\mathrm{~S}_{\text {tearing }}$ & 1818 & 827 & $w<0,3$ & & & & \\
\hline & $v=0,15$ & 1559 & 439 & 0,153 & X (33\%) & $\mathrm{N}$ & Y & $x$ \\
\hline & $v=0,20$ & 1625 & 493 & 0,148 & X (39\%) & $\mathrm{N}$ & Y & $x$ \\
\hline & $v=0,35$ & 1721 & 603 & 0,154 & $X(49 \%)$ & $Y$ & Y & Y \\
\hline \multirow{4}{*}{$g=0,75$} & $\mathrm{~S}_{\text {tearing }}$ & 2087 & 827 & $w<0,3$ & & & & \\
\hline & $v=0,10$ & 1807 & 401 & 0,136 & $X(31 \%)$ & $\mathrm{N}$ & Y & $x$ \\
\hline & $v=0,15$ & 1845 & 455 & 0,132 & $X(36 \%)$ & $\mathrm{N}$ & Y & Y \\
\hline & $v=0,20$ & 1883 & 511 & 0,128 & $X(40 \%)$ & $\mathrm{N}$ & Y & $Y$ \\
\hline \multicolumn{2}{|c|}{ Type "V" } & \multicolumn{2}{|c|}{$\mathrm{S}_{\text {allowed }}=\mathrm{K}_{\mathrm{i}} \mathrm{S}_{\text {calc }}$} & node 6 & *Prestressing & $g+w$ i $g+s+w$ & node 6 & tones I and II \\
\hline & $\mathrm{S}_{\text {tearing }}$ & 1421 & 827 & $w<0,3$ & & & & \\
\hline \multirow{3}{*}{$g=0,15$} & $v=0,10$ & 1130 & 357 & 0,128 & X (5\%) & $Y$ & Y & $\mathrm{N}$ \\
\hline & $v=0,15$ & 1164 & 394 & 0,122 & $X(12 \%)$ & Y & Y & $Y$ \\
\hline & $v=0,20$ & 1198 & 432 & 0,116 & $X(18 \%)$ & $\sqrt{ }$ & Y & $Y$ \\
\hline \multirow{4}{*}{$g=0,30$} & $\mathrm{~S}_{\text {tearing }}$ & 1649 & 827 & $w<0,3$ & & & & \\
\hline & $v=0,10$ & 1286 & 343 & 0,115 & X (8 \%) & Y & Y & $\mathrm{N}$ \\
\hline & $v=0,15$ & 1322 & 382 & 0,109 & $X(15 \%)$ & $Y$ & Y & $Y$ \\
\hline & $v=0,20$ & 1361 & 425 & 0,104 & $X(22 \%)$ & $Y$ & Y & $Y$ \\
\hline \multirow{4}{*}{$g=0,50$} & $\mathrm{~S}_{\text {tearing }}$ & 1818 & 827 & $w<0,3$ & & & & \\
\hline & $v=0,10$ & 1478 & 327 & 0,104 & X (9 \%) & Y & Y & $\mathrm{N}$ \\
\hline & $v=0,15$ & 1516 & 369 & 0,097 & $X(16 \%)$ & $Y$ & Y & $Y$ \\
\hline & $v=0,20$ & 1553 & 411 & 0,093 & $X(22 \%)$ & Y & Y & $Y$ \\
\hline \multirow{4}{*}{$g=0,75$} & $\mathrm{~S}_{\text {tearing }}$ & 2087 & 827 & $w<0,3$ & & & & \\
\hline & $v=0,10$ & 1801 & 306 & 0,089 & $X(10 \%)$ & Y & Y & $x$ \\
\hline & $v=0,15$ & 1762 & 353 & 0,085 & $X(17 \%)$ & Y & Y & $Y$ \\
\hline & $v=0,20$ & 1722 & 398 & 0,082 & $X(23 \%)$ & $Y$ & $\sqrt{ }$ & $Y$ \\
\hline
\end{tabular}

analysed girder. Design prestressing forces that should be introduced into the cable truss via the stabilizing cable in order to obtain a fully stable structure, for the adopted models "D" and "V" and defined load values, taking into account additional fictive load values from Table 8 , are presented in Figure 9. 
Table 8. Fulfilment of dynamic resistance criteria

\begin{tabular}{|c|c|c|c|c|c|}
\hline \multirow{2}{*}{$\begin{array}{l}\text { Models } \\
\text { type }\end{array}$} & \multirow{2}{*}{$\begin{array}{c}\text { Additional } \\
\text { fictive load } \\
{\left[\mathrm{kN} / \mathrm{m}^{2}\right]}\end{array}$} & \multicolumn{4}{|c|}{$\begin{array}{l}\text { Category of roof dead load } \\
\qquad\left[\mathrm{kN} / \mathrm{m}^{2}\right]\end{array}$} \\
\hline & & $g=0,15$ & $g=0,30$ & $g=0,50$ & $g=0,75$ \\
\hline \multirow{5}{*}{ Type "D" } & $v=0,15$ & $N$ & $N$ & $N$ & $\mathrm{~N}$ \\
\hline & $v=0,20$ & $\mathrm{~N}$ & $N$ & $N$ & DynR \\
\hline & $v=0,35$ & $N$ & $\mathrm{~N}$ & DynR & \\
\hline & $v=0,50$ & $N$ & DynR & & \\
\hline & $v=0,70$ & DynR & & & \\
\hline \multirow{3}{*}{ Type "V" } & $v=0,10$ & $N$ & $\mathrm{~N}$ & $\mathrm{~N}$ & $\mathrm{~N}$ \\
\hline & $v=0,15$ & $\mathrm{~N}$ & $\mathrm{~N}$ & $\mathrm{~N}$ & $\mathrm{~N}$ \\
\hline & $v=0,20$ & DynR & DynR & DynR & DynR \\
\hline
\end{tabular}

\section{Conclusions}

A structure is considered stable when tensioned with forces according to the above mentioned criteria for a particular roof load category and an additional fictive load " $\mathrm{v}$ ", in accordance with Table 8.

The model "D" has confirmed its repute of being "unmovable" for heavyweight roof covers and for a regular level of prestressing $v=0,20 \mathrm{kN} / \mathrm{m}^{2}$, while for lightweight roof covers, the prestressing levels must be increased significantly, i.e. by up to two times when compared to the model "V" (Figure 9). At that, an additional fictive load of $v=0.70 \mathrm{kN} / \mathrm{m}^{2}$ must be applied in order to meet the above mentioned criteria (Table 8).

\section{REFERENCES}

[1] Jawerth, D., Schulz, H.: Ein Beitrag zur Eigenschwingungen, windanfachenden Krafte und aerodynamischen Stabilität bei hangenden Dachern, Der Stahlbau, Berlin, 1966. (in German)

[2] Majowiecki, M.: HS steels in tension structures, (keynote lecture), Proceedings of 1st International conference Super High Strength Steels, Rome, Italy, 2005

[3] Bolanos-Sanches, R., Sanchez-Arcilla, A., Cateura, J.: Evaluation of Two Atmospheric Models for Wind-Wave Modelling in the NW Mediterranean, Journal of Marine Systems, 2006.

[4] Holmes, J.: Codification of Wind Loads on Wind-sensitive Structures, International journal of space structures, ISSN 02663511, 24(2), pp.87-95, 2009.

[5] Sachs, P.: The influence of wind on structures, GK Beograd, 1986. (in Serbian)

[6] Schlaich, J.: About light-weight structures, Izgradnja (7) Beograd 1988. (in Serbian)

[7] Kostić, D.: Contribution To The Solution Of The Stability Problem Of The Double Layered Catenary Systems, doktorska disertacija, Faculty of Civil Engineering and Architecture Niš, Serbia,.2007. (in Serbian)

[8] AISI: Manual for Structural Applications of Steel Cables for Buildings, ASCE Standard 19-96, 2010.

[9] Eurocode 3: Design of steel structures - Part 1-11: Design of structures with tension components, BS EN 1993-1-11:2006

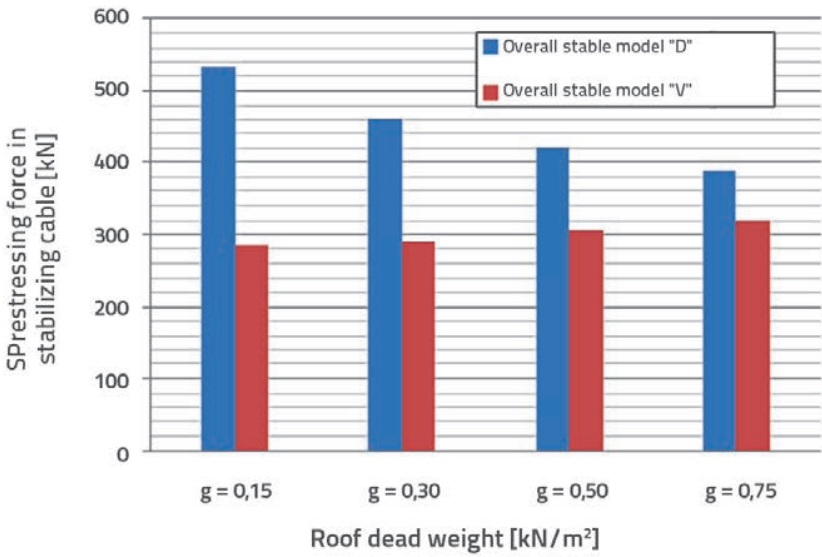

Figure 9. Prestressing forces ratio for models "D" and "V", for different roof weight categories

The model "V", although considered a "movable" type of structure, has been proven to be a dynamically resistant and comprehensively stable structure for all roof-cover categories, and for the regular prestressing level $v=0,20 \mathrm{kN} / \mathrm{m}^{2}$.

Computations conducted in this paper refer to two most frequently used cable truss models, "D" and "V",60 m in span. The derived conclusions point to the introduction of an appropriate additional fictive load as a parameter that influences the prestressing level at which stability criteria will be fulfilled. Moreover, the cable-girder global security coefficient will be increased if criteria suggested in Section 4 are used. This also enables definition of the girder stability level as related to the additional fictive load level and the prestressing force applied.

[10] Eurocode 1: Actions on structures - Part 1-4: General actions Wind actions, EN1991-1-4:2005+A1

[11] Krishna, P.: Cable suspended roofs, McGraw Hill, London, 1986.

[12] Lewis, W.: Tension Structures-Form and Behavior, Tomas Telford Edition, 2003.

[13] Lewis, W.: Computational form-finding methods for fabric structures, Proceedings of the ICE - Engineering and Computational Mechanics, Volume 161, Issue 3, 2008., pp.139 $-149$.

[14] Travaš, V., Kožar, I.: Static and dynamic analysis of a spatial catenary, GRADEVINAR 60 (2008) 5, pp. 395-402, (in Croatian)

[15] Zhang, Z., Cheng, W.: Proper shape analyses of spatial cable frames, International Journal of Space structures, Vol. 26 No.2, pp.95-104, 2011.

[16] Zhang, X.: Investigation on the wind-induced instability of long-span suspension bridges with 3D cable system, Wind and Structures, 14 (3), 2011.

[17] Balgac, E.: Die neue Ausstelungshalle der Textilmesse in Leskovac, Beton und Stahlbetonbau, (7), 1961. (in German)

[18] Balgač, E.: Determining force in the cable network of prestressed hanging hyperbolic paraboloid roofshape, Izgradnja, $(11,12)$, Beograd 1969. (in Serbian) 